TAO, Vol. 16, No. 1, 113-136, March 2005

\title{
Bacterial Activity and Their Physiological Characteristics in the Sediments of ODP Holes 1202A and 1202D, Okinawa Trough, Western Pacific
}

\author{
Jiin-Shuh Jean $^{1, *}$, Tzen-Yuh Chiang ${ }^{2}$, Kuo-Yen Wei ${ }^{3}$, Wei-Teh Jiang ${ }^{1}$, \\ Chia-Chuan Liu ${ }^{1}$, and Yen-Ping Tsai ${ }^{1}$
}

(Manuscript received 8 April 2004, in final form 18 November 2004)

\begin{abstract}
Bacterial strains were isolated and identified from the down-core sediments of Site 1202 of ODP Leg 195 in the Okinawa Trough. Their phylogenetic relationships and physiological characteristics were determined. The isolates were cultured in aerobic and anaerobic sulfate-reducing and fermentative media at temperatures of $30^{\circ} \mathrm{C}$ and $45^{\circ} \mathrm{C}$. The results showed that there were gram-positive/negative rod- and/or sphere-shaped bacteria in the sediments at all depths from 3 to 358.3 meters below the seafloor (mbsf), but no bacteria were present at depths greater than $358.3 \mathrm{mbsf}$ ( $>64.73 \mathrm{ka}$ in age of sediment) were isolated (maximum core depth $406.5 \mathrm{mbsf}$ ). On the basis of the nucleotide similarities of $16 \mathrm{~S}$ rDNA and reconstructed phylogeny, the bacterial isolates of the sediments of $10.1 \mathrm{mbsf}(1202 \mathrm{A002H})$ and $241.2 \mathrm{mbsf}$ (1202D027X) were shown to share high identities with the Bacillus subtilis and Pseudomonas putida or $\gamma$-proteobacterium MPD-98 strains. Physiological experiments showed that the optimal temperature for growth of the studied bacteria was $30^{\circ} \mathrm{C}$ but the bacteria obtained at some depths could tolerate temperatures up to $45^{\circ} \mathrm{C}$. The maximum salinity allowed for the growth of the cultured bacteria was $60-65 \%$. The optimal pH for bacterial growth was 7.0 - 8.3. None of the bacteria extracted from the studied sediments could survive at $\mathrm{pH} \leq 5$ or $\geq 11$. These halotolerant bacteria were capable of making consumption of $\mathrm{Fe}, \mathrm{Cu}^{2+}, \mathrm{Na}^{+}$, $\mathrm{K}^{+}, \mathrm{Mg}^{2+}, \mathrm{Ca}^{2+}$, and $\mathrm{F}^{-}$, but no biogenic minerals could be identified in the present study.
\end{abstract}

\footnotetext{
${ }^{1}$ Department of Earth Sciences, National Cheng Kung University, Tainan, Taiwan, ROC

2 Department of Biology, National Cheng Kung University, Tainan, Taiwan, ROC

${ }^{3}$ Department of Geosciences, National Taiwan University, Taipei, Taiwan, ROC

* Corresponding author address: Prof. Jiin-Shuh Jean, Department of Earth Sciences, National Cheng Kung University, Tainan, Taiwan, ROC; E-mail: jiinshuh@mail.ncku.edu.tw
} 


\section{(Keywords: Site 1202 of ODP Leg 195, Okinawa Trough, 16S rDNA, Bacterial activity, Physiology, Phylogeny)}

\section{INTRODUCTION}

Subsurface microbes have been widely found to be present in seafloor sediments (Bidle et al. 1999; Bird et al. 2001; Cragg et al. 1994; Kormas et al. 2003; Swart et al. 2000; WDCMGG 2001; Webster et al. 2003; Whiticar et al. 1995). Highly diverse bacterial communities may be present at depths as evidenced by those harbored in the deep subsurface sediments (analyzed by $16 \mathrm{~S}$ rDNA sequencing) of the fore-arc basin in Nankai Trough, southeastern Japan (ODP Site 1176) (Kormas et al. 2003). The microbial population can be as high as $>10^{9}$ cells per gram dry sediment weight as that found in the organic-rich sediments throughout the entire Holocene section in ODP Leg 169S, Saanich Inlet, British Columbia, Canada (Bird et al. 2001). However, microbial abundance may decrease dramatically with increasing depths. For example, Whiticar et al. (1995) found that bacterial population decreased from $1.27 \times 10^{9} \mathrm{cells} \mathrm{cm}^{-3}$ at the seafloor surface to $2.51 \times 10^{6}$ cells cm${ }^{-3}$ at $68.28 \mathrm{mbsf}$ (a 505 fold decrease) in Santa Barbara Basin, ODP Site 893. Nevertheless, the detection of bacterial type and occurrence is fundamentally important for an understanding of the relationship between microbiological behavior and changes in physio-chemical conditions in seafloor sediments. The bacteria may be present as a spore and can survive in geological formations without nutrient supply. The spore or existing bacteria can be re-activated or bred via different media (e.g., iron-reducing, sulfate-reducing, fermentative, and denitrifying). The interaction between microbes and minerals may significantly affect the geochemical behavior of an element and possibly cast important implications for geomagnetic signals related to formation of magnetic iron sulfide or oxide minerals (Liu et al. 1997; Mann et al. 1990; Blakemore et al. 1979; Frankel et al. 1979).

The interactions between microbes and geological processes have been reported in many studies. WDCMGG (2001) reported that abundant supply of organic-rich matter in sediments that underlie areas of coastal upwelling on a given continental shelf would allow sulfate-reducing bacteria and methanogens to dominate diagenesis, and create an environment ideal for the formation of sulfides, calcite, dolomite, and phosphorites. The reported sites are located in the offshore regions of western South America including the Lima, Salaverry, Trujillo, and Pisco fore-arc basins, as well as the accretionary complex of the Peru continental margin. A brine incursion in the Peru Margin was shown to stimulate bacterial activity and to increase bacterial viability at a depth of 80 mbsf with an age of $\sim 1$ Ma (WDCMGG 2001). A deep brine incursion at Site 977/978 of the Alboran Sea, western Mediterranean, supplied the sulfate nutrients for microbes below $400 \mathrm{mbsf}$ (Cragg et al. 1999). Swart et al. (2000) also found an abnormally high salinity content $(106 \%)$ in the fluid of the Miocene-Pleistocene sediments at about $400 \mathrm{mbsf}$ in the south Australian margin of ODP Leg 182. These saline fluids may play an important role in microbial activities.

Direct isolation of nucleic acids from sediments provides high-molecular-weight chromosomal DNA, plasmid DNA, and speciated RNAs which co-migrate with 16S rRNAs. The method has been proven useful in studying both the ecology and the phylogeny of microbes 
that resist classical cultural methods (Somerville et al. 1992). For example, the diversity of bacterial communities in deep marine sediments, up to 503 meters below the seafloor of the Japan sea, was successfully investigated by sequence analysis of amplified 16S rRNA genes (Rochelle et al. 1994).

During the cruise of ODP Leg 195, sediments from the seafloor down to $117.5 \mathrm{mbsf}$ were collected for this study from Holes 1202A ( $\left.24^{\circ} 48.2449^{\prime} \mathrm{N}, 122^{\circ} 30.0002^{\prime} \mathrm{E}\right)$, and samples from 119 - 406.5 mbsf in Hole 1202D ( $\left.24^{\circ} 48.2456^{\prime} \mathrm{N}, 122^{\circ} 30.0259^{\prime} \mathrm{E}\right)$ in the southern Okinawa Trough, western Pacific. Sediments from Holes 1202B and 1202C were not included in this study. The southern Okinawa Trough is an area of high sedimentation rates because of an enormous terrigenous sediment supply from the East China Sea shelf and Taiwan (Boggs et al. 1979; Lin and Chen 1983; Chen et al. 1992). The deposits in the vicinity of Holes 1202A and $1202 \mathrm{D}$ are primarily clay to silt-sized sediments with a moderate content of carbonate (3 15\%) (Shipboard Scientific Party 2002). The contained indigenous bacteria were isolated from all sampled depths of sediments in the present study to investigate the occurrence, distribution, motility, inorganics utilization for growth, and physiological characteristics (i.e., temperature, salinity, and $\mathrm{pH}$ ) of the bacteria in the sediments. This will lead to a better understanding of how indigenous bacteria can survive in deep subsurface environments.

\section{MATERIALS AND METHODS}

\subsection{Sediment Sampling and Preservation}

A total of forty-two samples from Holes A and D of Site 1202 were collected on board during Leg 195. The samples were retrieved from drilling cores (one sample per two cores with a coring interval of $9.5 \mathrm{~m}$ ) with a specially designed device consisting of a stainless steel cork and plunger in order to prevent contamination on the indigenous bacteria. The samples consist principally of bioturbated homogeneous clayey silt, occasionally with a high sand content (Shipboard Scientific Party 2002).

A stainless steel cork and plunger set was used for the collection of the studied sediment samples. The cork and plunger were submerged in $70 \%$ ethanol for 5 seconds then shaken to get rid of excess liquid, and allowed to air dry for a few seconds. The cork was then pushed into the sediment from the break between cut sections. Sections were not cut by spatula but twisted at the core liner. Therefore no external object came in contact with the sediment itself while sampling.

Approximately 10 - $15 \mathrm{ml}$ of sediment for each sample was taken from several "plugs" and placed into prepared glass bottles (Shipboard Scientific Party 2002). The screw top was immediately closed. The samples were then taken into the shipboard Microbiology Laboratory, where the sample bottle was flushed with $\mathrm{N}_{2}$ for 20 - 30 seconds to replace as much air as possible. The cap was then sealed and the whole specimen bottle was refrigerated at $4{ }^{\circ} \mathrm{C}$.

After the ship arrived at the Keelung Harbor, the samples were transported to the Hydrogeology Laboratory of Department of Earth Sciences of National Cheng Kung University for microbial analyses. Each of the forty-two samples was transferred into an anti-freeze container and then refrigerated at $-70^{\circ} \mathrm{C}$ for a longer preservation. 


\subsection{Bacteria Extraction from Sediment and Enrichment Cultures}

The extraction of bacteria from sediment was performed according to Lehman et al. (1995). About $0.1-0.2 \mathrm{~g}$ of material was taken from each sample and placed into a flask containing $10 \mathrm{ml}$ of $0.1 \%$ sodium pyrophosphate solution. The culture solution was shaken continuously for 24 hours at $150 \mathrm{rpm}$ in a rotary shaker at room temperature $\left(\sim 25^{\circ} \mathrm{C}\right)$, enabling the bacteria to be eluted into the suspended solution from the sediment. Approximately $0.5 \mathrm{ml}$ of bacteriabearing fluid was taken with a pipette and injected into a Hungate tube that contains a liquid medium for sulfate-reducing or fermentative culturing.

A TYG medium (trypticase-yeast extract glucose) for preserving the fermentative bacteria was prepared. The composition of the TYG medium for fermentative bacteria is listed in Table 1. The medium was placed in a vessel with 1 liter $\mathrm{dd}_{2} \mathrm{O}$ (deionized water) (pH 7 - 7.2) and heated until boiling. After the substance was cooled with ice cubes, nitrogen was added and the $\mathrm{pH}$ was adjusted to $7-7.2$ with $\mathrm{NaOH}$. The bacteria-bearing fluid of $10 \mathrm{ml}$ in volume was then transferred from the vessel into a Hungate tube with a pipette. Nitrogen was added and the cap subsequently sealed.

The preparation of the sulfate-reducing medium was performed using the ingredients listed in Table 2. When the bacteria-bearing fluid turned turbid due to a reaction with the media, it was transferred to another Hungate tube with a pipette. This procedure was repeated three times in order to ensure that sufficient bacteria were cultured. The hybrid-cultured bacteria were isolated into a pure culture using four-way streak plate inoculation. This procedure was repeated twice to ensure that a pure culture was achieved. The pure culture of bacterial strain was then injected into liquid media for culture enrichment. DNA extraction was performed after the bacteria were sufficiently incubated.

Table 1. The composition of the TYG medium for fermentative bacteria (modified from Jensen et al. 1998).

\begin{tabular}{|c|c|c|c|}
\hline Constituents & Weight or volume & Constituents & Weight or volume \\
\hline $\mathrm{K}_{2} \mathrm{HPO}_{4}$ & $0.8 \mathrm{~g}$ & Trypticase peptone & $10 \mathrm{~g}$ \\
\hline $\mathrm{KH}_{2} \mathrm{PO}_{4}$ & $0.2 \mathrm{~g}$ & Yeast extract & $1.0 \mathrm{~g}$ \\
\hline $\mathrm{MgSO}_{4} \cdot 7 \mathrm{H}_{2} \mathrm{O}$ & $0.24 \mathrm{~g}$ & ${ }^{2}$ Sodium Thioglycollate & $0.5 \mathrm{~g}$ \\
\hline${ }^{1}$ Solution $\mathrm{M}$ & $0.5 \mathrm{ml}$ & Glucose & $10 \mathrm{~g}$ \\
\hline $0.2 \mathrm{M} \mathrm{FeSO}_{4}\left(\right.$ in $\left.0.1 \mathrm{M} \mathrm{H}_{2} \mathrm{SO}_{4}\right)$ & $0.2 \mathrm{ml}$ & Deionized water & 1 liter \\
\hline
\end{tabular}

${ }^{1}$ Solution $\mathrm{M}$ consists of $1.26 \mathrm{~g} \mathrm{MnCl}_{2}, 3.33 \mathrm{~g} \mathrm{CaCl}, 0.65 \mathrm{~g} \mathrm{CoCl}_{2}, 1.03 \mathrm{~g}$ $\mathrm{Na}_{2} \mathrm{MnO}_{4}$, and 1 liter deionized water.

${ }^{2}$ No need for an aerobic culture. 
Table 2. The composition of the sulfate-reducing medium (modified from Blakemore et al. 1979 and Leu et al. 1999).

\begin{tabular}{|c|c|c|c|}
\hline Constituents & Weight or volume & Constituents & Weight or volume \\
\hline $\mathrm{NaCl}$ & $2 g$ & ${ }^{3} \mathrm{NaHCO}_{3}$ solution & $30 \mathrm{ml}$ \\
\hline $\mathrm{MgCl}_{2} \cdot 6 \mathrm{H}_{2} \mathrm{O}$ & $0.4 \mathrm{~g}$ & ${ }^{4}$ Sulfide solution & $7.5 \mathrm{ml}$ \\
\hline $\mathrm{CaCl}_{2} \cdot 2 \mathrm{H}_{2} \mathrm{O}$ & $0.1 \mathrm{~g}$ & 5 Vitamin mixture & $1 \mathrm{ml}$ \\
\hline $\mathrm{Na}_{2} \mathrm{SO}_{4}$ & $4 \mathrm{~g}$ & Yeast extract & $1 \mathrm{~g}$ \\
\hline $\mathrm{NH}_{4} \mathrm{Cl}$ & $0.25 \mathrm{~g}$ & Lactate & $1 \mathrm{~g}$ \\
\hline $\mathrm{KH}_{2} \mathrm{PO}_{4}$ & $0.2 \mathrm{~g}$ & Acetatic acid & $1.64 \mathrm{ml}$ \\
\hline $\mathrm{KCl}$ & $0.5 \mathrm{~g}$ & n-Butyratic acid & $1.1 \mathrm{ml}$ \\
\hline Resazurin & $1 \mathrm{ml}$ & Propionate & $1.54 \mathrm{~g}$ \\
\hline${ }^{1}$ Trace element & $1 \mathrm{ml}$ & Deionized water & $959.5 \mathrm{ml}$ \\
\hline${ }^{2}$ Selenite solution & $1 \mathrm{ml}$ & & \\
\hline
\end{tabular}

${ }^{1}$ Trace element consists of $6.5 \mathrm{ml} \mathrm{HCl}(25 \% \mathrm{w} / \mathrm{v}), 1.5 \mathrm{~g} \mathrm{FeCl}_{2} \cdot 4 \mathrm{H}_{2} \mathrm{O}, 60 \mathrm{mg}$ $\mathrm{H}_{3} \mathrm{BO}_{3}, 100 \mathrm{mg} \mathrm{MnCl}_{2} \cdot 4 \mathrm{H}_{2} \mathrm{O}, 120 \mathrm{mg} \mathrm{CoCl} \mathrm{Cl}_{2} \cdot 6 \mathrm{H}_{2} \mathrm{O}, 70 \mathrm{mg} \mathrm{ZnCl}, 25 \mathrm{mg}$ $\mathrm{NiCl}_{2} \cdot 6 \mathrm{H}_{2} \mathrm{O}, 15 \mathrm{mg} \mathrm{CuCl} \mathrm{m}_{2} \cdot 2 \mathrm{H}_{2} \mathrm{O}, 25 \mathrm{mg} \mathrm{Na}{ }_{2} \mathrm{MoO}_{4} \cdot 2 \mathrm{H}_{2} \mathrm{O}$;

${ }^{2}$ Selenite Solution: $3 \mathrm{mg} \mathrm{H}_{2} \mathrm{SeO}_{3}$, $400 \mathrm{mg} \mathrm{NaOH}, 1000 \mathrm{ml} \mathrm{H}_{2} \mathrm{O}$;

${ }^{3} \mathrm{NaHCO}_{3}$ Solution: $5.88 \mathrm{~g} \mathrm{NaHCO}_{3}, 70 \mathrm{ml} \mathrm{H} \mathrm{H}_{2} \mathrm{O}$;

${ }^{4}$ Sulfide solution: $250 \mathrm{ppm} \mathrm{Na}{ }_{2} \mathrm{~S} \cdot \mathrm{E} 9 \mathrm{H}_{2} \mathrm{O}, 100 \mathrm{ml} \mathrm{H} \mathrm{H}_{2} \mathrm{O}$;

${ }^{5}$ Vitamin mixture: $5 \mathrm{mg}$ P-aminobenzoic acid, $1 \mathrm{mg}$ d-biotin, $10 \mathrm{mg}$ nicotinic acid, $5 \mathrm{mg}$ pantothenic acid, $15 \mathrm{mg}$ pyridooxal, $10 \mathrm{mg}$ thiamine, $5 \mathrm{mg}$ vitamin $\mathrm{B}_{12}$, and $5 \mathrm{mg}$ riboflavin.

\subsection{DNA Isolation}

Bacterium DNA was extracted using the DNA/RNA extraction kit (Viogen, Sunnyvale, CA, USA) according to the manufacture's instruction. A detailed description of the procedures for DNA isolation is provided in its instruction manual.

\subsection{Polymerase Chain Reaction (PCR) Amplification}

The 16S rRNA gene region of the DNA was amplified by the PCR using a pair of universal primers. The oligonucleotide sequences for the forward primer (16f27) and the reverse primer (16r1488) were 5'-AGAGTTTGATCMTGGCTCAG-3' (genomic positions 8 to 27) 
and 5'-CGGTTACCTTGTTAGGACTTCACC-3' (genomic positions 1488 to 1511), respectively (Bennasar et al. 1998). Each $100 \mu \mathrm{l}$ PCR reaction contained: $10 \mathrm{ng}$ template DNA, $10 \mu \mathrm{l}$ $10 \times$ reaction buffer, $10 \mu \mathrm{l} \mathrm{MgCl}_{2}(25 \mathrm{mM}), 10 \mu \mathrm{l}$ dNTP mix $(8 \mathrm{mM}), 10$ pmole of each primer, and $4 \mathrm{U}$ of Taq polymerase (Promega, Madison, WI, USA). The reaction was carried out on a MJ Thermal Cycler (Genetic Research Instruments, Braintree, Essex, UK) programmed to have the sequence of (1) a first cycle of denaturation at $95^{\circ} \mathrm{C}$ for 2 minutes, (2) 30 cycles of denaturation at $94^{\circ} \mathrm{C}$ for 45 seconds, (3) annealing at $56^{\circ} \mathrm{C}$ for 75 seconds; (4) extension at $72{ }^{\circ} \mathrm{C}$ for 90 seconds, (5) $72^{\circ} \mathrm{C}$ stabilization for 10 minutes, and (6) storage at $4^{\circ} \mathrm{C}$.

\subsection{T-Vector Cloning and Nucleotide Sequencing}

All PCR products were purified from an agarose gel using the PCR product purification kit (Viogene) and cloned into a pGEM-T easy cloning vector (Promega). For each 16S rRNA gene fragment, both strands were cycle-sequenced using the Taq Dye Deoxy Terminator Cycle Sequencing Kit (Applied Biosystem, Foster City, CA, USA). Products of the cycle sequencing reactions were run on an ABI 377XL automated sequencer (Applied Biosystem). Cloned PCR products were sequenced using universal T7 forward (5' - TAATACGACTCACTATACGGG3') and SP6 reverse (5'-TATTTAGGTGACACTATAG-3') primers located on pGEM-T easy vector termination sites.

\subsection{Sequence Alignment and Phylogenetic Analysis}

The internal transcribed spacer (ITS) sequences were searched via BLAST, a function implemented in NCBI GenBank, to obtain homologous sequences of other bacteria. Nucleotide sequences of the ribosomal ITS were aligned with the program CLUSTAL X 1.81 (Thompson et al. 1997). Neighbor-joining (NJ) analysis based on Kimura's (1980) two-parameter distance was performed using the software MEGA 2.0 (Kumar et al. 2001). Confidence of the clade reconstruction was tested by bootstrapping (Felsenstein 1985) with 1000 replicates using unweighted characters.

\subsection{Gram Stain Techniques}

The bacteria were stained using the Gram stain technique described by the manufacture's instructions (Meditech Biotechnology Co., Ltd., Taipei, Taiwan). A drop of immersion oil was added onto the stained bactieral specimens for morphological observation of the bacteria under a $1000 \times$ microscope. The gram-positive (shown in blue) or negative (shown in pink to purple) bacteria could then be identified. A detailed description of the stain procedures is given in its instruction manual.

\subsection{Physiological Testing on Bacterial Isolates}

\subsubsection{Temperature}

The mixture of sulfate-reducing media was placed into five separate Hungate tubes. The 
media were tilted slightly until they coagulated, then the bacteria from the liquid sulfate-reducing media were introduced into agar using an inoculating loop. Finally, nitrogen gas was added and the container was sealed with a cap in order to maintain anaerobic conditions. The five tubes were then placed into five separate incubators at $-10^{\circ} \mathrm{C}, 0^{\circ} \mathrm{C}, 30^{\circ} \mathrm{C}, 45^{\circ} \mathrm{C}$, and $60^{\circ} \mathrm{C}$ for culturing.

\subsubsection{Salinity}

Eleven different concentrations of sodium chloride including 8.8, 11, 15, 18, 21, 28, 35, $40,50,60$, and $65 \%$ were placed into eleven separate Hungate tubes. They were combined with a sulfate-reducing media and agar and slightly tilted until they coagulated. Then the bacteria from the liquid sulfate-reducing media were introduced into the agar using an inoculating loop and subsequently combined with nitrogen gas and sealed with a cap in order to maintain anaerobic conditions. These tubes were then placed in an incubator for culturing at $30^{\circ} \mathrm{C}$.

\section{$2.8 .3 \mathrm{pH}$}

Seven separate Hungate tubes were filled with sulfate-reducing media and adjusted to different $\mathrm{pH}$ levels (i.e., $\mathrm{pH}=5$ - 11) and tilted slightly until the media coagulated. The bacteria from the liquid sulfate-reducing media were then introduced into the agar using an inoculating loop and subsequently combined with nitrogen gas and sealed with a cap in order to maintain anaerobic conditions. These tubes were then placed into an incubator for culturing at $30^{\circ} \mathrm{C}$.

\subsection{Bacterial Population and Motility}

Bacterial populations for the indigenous bacteria in the sediments were enumerated within DAPI (4',6-Diamidino-2-phenylindole) stained cells (Weinbauer et al. 1998) on a Zeiss MC80 Axioskop fluorescence microscope (Carl Zeiss, Oberkochen, Germany).

In motility test, $0.7 \%$ agar was added into a tube. After the agar coagulated, single strain bacteria from the liquid culture media were then vertically inserted into the agar using an inoculating loop, in which a clear straight line of the pathway through which the inoculating bacteria traveled could be seen. The motile bacteria were defined as the inoculating bacteria that could travel away from the pathway like a Christmas tree, while the non-motile bacteria were excluded.

\subsection{Mineralogical Analysis and Morphological Observation}

X-ray diffraction and scanning electron microscopy (SEM) in association with energy dispersive spectroscopy (EDS) were utilized to identify any possible biogenic minerals. Morphological observation was performed using a bright field phase-contrast microscope and a transmission electron microscope operated at $80 \mathrm{kV}$. 


\section{RESULTS AND DISCUSSIONS}

\subsection{Gram-positive and Negative Bacteria and their Morphologies}

The bacteria taken from the sediment samples of different depths ( 3 - $406.5 \mathrm{mbsf}$ ) were cultured in the fermentative and sulfate-reducing media at five different temperatures $\left(-10^{\circ} \mathrm{C}\right.$, $0^{\circ} \mathrm{C}, 30^{\circ} \mathrm{C}, 45^{\circ} \mathrm{C}$, and $60^{\circ} \mathrm{C}$ ). Table 3 shows the results of Gram stain test and morphological observation on the bacteria isolated from specimens cultured at $30^{\circ} \mathrm{C}$ and $45^{\circ} \mathrm{C}$, in which the bacteria grew best (see sections below). It is obvious that the rod-shaped bacteria were present only in the sediments at depths of $3(1202 \mathrm{~A} 001 \mathrm{H}), 10.1(1202 \mathrm{~A} 002 \mathrm{H}), 29.1(1202 \mathrm{~A} 004 \mathrm{H})$, $250.8(1202 \mathrm{D} 028 \mathrm{X})$, and 281.1(1202D031X) mbsf. The bacteria in the sediments $300.4 \mathrm{mbsf}$ were isolated from the aerobic fermentative media. This implies that the bacteria in the sediments at such depths could be adapted to aerobic conditions (G- spheres). Except for the rodshaped bacteria found at depths of 3, 10.1, 29.1, 250.8, and $281.1 \mathrm{mbsf}$, gram- positive/negative sphere-shaped bacteria were present in all sediments at depths between $3-358.3$ mbsf. No bacteria at depths greater than $358.3 \mathrm{mbsf}$ ( $>64.73 \mathrm{ka}$ in sediment age) were isolated using fermentative and sulfate-reducing media (maximum core depth $406.5 \mathrm{mbsf}$ ). The entire sequence of sediments covers a range of age from 1.62 to $67.62 \mathrm{ka}$ (Table 3).

The bacteria from different depths of the sediments were also cultured anaerobically using sulfate-reducing media. The morphology of the cultured bacteria varies with sediment depths (Fig. 1). Rod-shaped bacteria were mainly found to exist in shallower sediments depths and their populations after culturing appear to decrease with depth. Sphere-shaped bacteria (cocci) were found in more specimens. Figure 1 shows a few examples of the cultured bacteria. Stalked cells of rod-shaped bacteria in a dividing stage were observed in the core sediments at $250.8 \mathrm{mbsf}$ (1202D028X). The stalked cell possesses a prostheca attached to solid substrata (Fig. 1d). Differing from those from the same sediment sample, the bacterial colonies cultured from sediments of different depths neither had the same morphology nor utilized the same culture media. Several disseminated blue-purple crystals (not shown) found in the sediment at $300.4 \mathrm{mbsf}$ (Table 3 ) were isolated while culturing on the aerobic fermentative media at $30^{\circ} \mathrm{C}$. These unknown crystals were originally present in the sediment at $300.4 \mathrm{mbsf}$ and did not result from bacterial culturing. Their origin cannot be positively determined in the present study.

\subsection{Bacterial Strain Identification and Phylogenetic Relationships}

A neighbor-joining (NJ) tree was reconstructed based on the genetically evolutional distance (data not shown) between nucleotide sequences of 16S rRNA gene rooted at Caulobacter crescentus (Fig. 2). Two major clades, supported significantly with bootstrapping, were identified. Sequences obtained in this study, the bacterial isolates $1202 \mathrm{A002H}$ (1025 bp of nucleotides) and 1202D027X (1034 bp of nucleotides) (GenBank accession numbers AY563616 and AY563617, respectively), are nested in the clade of Pseudomonas putida, $\gamma$-proteobacterium MPD-98, Bacillus subtilis, and Pseudomonas aeruginosa. In addition, the sequence identity comparisons across bacterial strains suggested an affinity of Bacillus subtilis and Pseudomonas putida or $\gamma$-proteobacterium MPD-98 strains for the bacterial isolates in the sediments of 
Table 3. The bacteria strains and their morphologies for the isolates incubated in fermentative and sulfate-reducing media at $30^{\circ} \mathrm{C}$ and $45^{\circ} \mathrm{C}$ for different depths of sediments.

\begin{tabular}{|c|c|c|c|c|c|c|c|}
\hline Sample no. & $\begin{array}{l}\text { Depth } \\
\text { (mbsf) }\end{array}$ & $\begin{array}{l}\text { Incubat. } \\
\text { temp. } \\
\left.{ }^{\circ} \mathrm{C}\right)\end{array}$ & $\begin{array}{l}\text { Gram stain and } \\
\text { morphology }\end{array}$ & Type of culture & $\begin{array}{l}\text { Cell count } \\
\left(10^{7} \text { cells } / g\right. \\
\text { sediment })\end{array}$ & Motility & $\begin{array}{l}\text { *Sediment } \\
\text { age (ka) }\end{array}$ \\
\hline $1202 \mathrm{~A} 001 \mathrm{H}$ & 3 & $30 / 45$ & $\begin{array}{l}G+\text { rods \& spheres } \\
G+\text { spheres }\end{array}$ & $\begin{array}{l}\text { Aer. \& Anaer. F; } \\
\text { Anaer. S./ Anaer. S. }\end{array}$ & 53 & No & 1.62 \\
\hline $1202 \mathrm{~A} 002 \mathrm{H}$ & 10.1 & 30 & $\mathrm{G}+$ rods & Anaer. S. & 127 & Yes & 2.82 \\
\hline $1202 \mathrm{~A} 004 \mathrm{H}$ & 29.1 & 30 & G-rods & Anaer. S. & 74 & Yes & 8.39 \\
\hline $1202 \mathrm{A006H}$ & 49.6 & 30 & G-spheres & Anaer. S. & 100 & Yes & 12.30 \\
\hline $1202 \mathrm{~A} 009 \mathrm{H}$ & 78.1 & 30 & G-spheres & $\begin{array}{l}\text { Aer. \& Anaer. F. } \\
\text { Anaer. S. }\end{array}$ & 75 & Yes & 19.22 \\
\hline $1202 \mathrm{~A} 012 \mathrm{H}$ & 106.6 & 30 & $\mathrm{G}+$ spheres & Anaer. S. & 217 & No & 30.71 \\
\hline $1202 \mathrm{D} 014 \mathrm{X}$ & 119 & 30 & $\begin{array}{l}\text { G- spheres; } \\
\text { G+ spheres }\end{array}$ & Anaer. S. & 108 & Yes & 31.99 \\
\hline 1202D020X & 176.8 & $30 / 45$ & G-spheres & $\begin{array}{l}\text { Aer. \& Anaer. S.; } \\
\text { Anaer. F./Anaer. S. }\end{array}$ & 117 & No & 36.01 \\
\hline $1202 D 021 X$ & 186.5 & 30 & $\begin{array}{l}\text { G- spheres } \\
\text { G+ spheres }\end{array}$ & Anaer. S. & 97 & Yes & 36.80 \\
\hline $1202 \mathrm{D} 027 \mathrm{X}$ & 241.2 & 30 & G-spheres & Anaer. S. & 171 & No & 45.56 \\
\hline $1202 \mathrm{D} 028 \mathrm{X}$ & 250.8 & 30 & $\mathrm{G}+\mathrm{rods}$ & Anaer. S. & 112 & Yes & 47.22 \\
\hline $12020030 x$ & 270 & 30 & G-spheres & Anaer. S. & 67 & Yes & 50.52 \\
\hline $1202 D 031 X$ & 281.1 & $30 / 45$ & G-rods & $\begin{array}{l}\text { Aer. \& Anaer. S.; } \\
\text { Anaer. F. } \\
\text { Aer. \& Anaer. S. }\end{array}$ & 87 & No & 52.46 \\
\hline $1202 \mathrm{D} 033 \mathrm{X}$ & 300.4 & 30 & G-spheres & Aer. F. & 76 & No & 55.99 \\
\hline $1202 D 035 X$ & 319.6 & 30 & G-spheres & Anaer. S.; Anaer. F. & 133 & Yes & 59.32 \\
\hline $1202 \mathrm{D} 039 \mathrm{X}$ & 358.3 & 30 & G+ spheres & Anaer. S. & 113 & Yes & 64.73 \\
\hline $1202 \mathrm{D} 040 \mathrm{X}$ & 367.9 & 30 & No growth & - & - & & 65.31 \\
\hline $1202 D 041 X$ & 377.6 & 30 & No growth & - & - & & 65.89 \\
\hline $1202 \mathrm{D} 042 \mathrm{X}$ & 387.2 & 30 & No growth & - & - & & 66.46 \\
\hline $12020043 X$ & 396.9 & 30 & No growth & - & - & & 67.05 \\
\hline $1202 \mathrm{D} 044 \mathrm{X}$ & 406.5 & 30 & No growth & - & - & & 67.62 \\
\hline
\end{tabular}

Anaer.: anaerobic; Aer.: aerobic; F.: incubated in fermentative media; S.: incubated in sulfate-reducing media.

G+: gram positive; G-: gram negative. *Sediment age can be referred to in Wei et al. 2005. 




Fig. 1. Bright field phase-contrast (left) and transmission electron (right) micrographs of the anaerobically cultured bacteria isolated from the sediments collected at ODP Holes 1202A and 1202D, Okinawa Trough: (a) bacteria cultured at $30^{\circ} \mathrm{C}$ from a $3-\mathrm{mbsf}$ sediment at $202 \mathrm{~A} 001 \mathrm{H}(\operatorname{rod} 0.6 \times 1.2 \mu \mathrm{m})$; (b) bacteria cultured at $30^{\circ} \mathrm{C}$ from a 10.1 -mbsf sediment at $1202 \mathrm{~A} 002 \mathrm{H}$ $(\operatorname{rod} 0.88 \times 1.2 \mu \mathrm{m})$; (c) bacteria cultured at $30^{\circ} \mathrm{C}$ from a $241.2-\mathrm{mbsf}$ sediment at 1202D27X (sphere $0.45-0.7 \mu \mathrm{m}$ ); (d) bacteria cultured at $30^{\circ} \mathrm{C}$ from a 250.8 -mbsf sediment at $1202 \mathrm{D} 028 \mathrm{X}(\operatorname{rod} 0.65 \times 1.15 \mu \mathrm{m})$; (e) bacteria cultured at $30^{\circ} \mathrm{C}$ from a $281.1-\mathrm{mbsf}$ sediment at $1202 \mathrm{D} 031 \mathrm{X}$ $(\operatorname{rod} 1.0 \times 1.9 \mu \mathrm{m})$. 
$10.1 \mathrm{mbsf}(1202 \mathrm{A002H}$; G+ rods) and $241.2 \mathrm{mbsf}$ (1202D027X; G- spheres) (Table 3). The high sequence similarity ( $\geq 94 \%$ ) of the two isolates shared with the sequences of these bacteria and the close phylogenetic affinity.

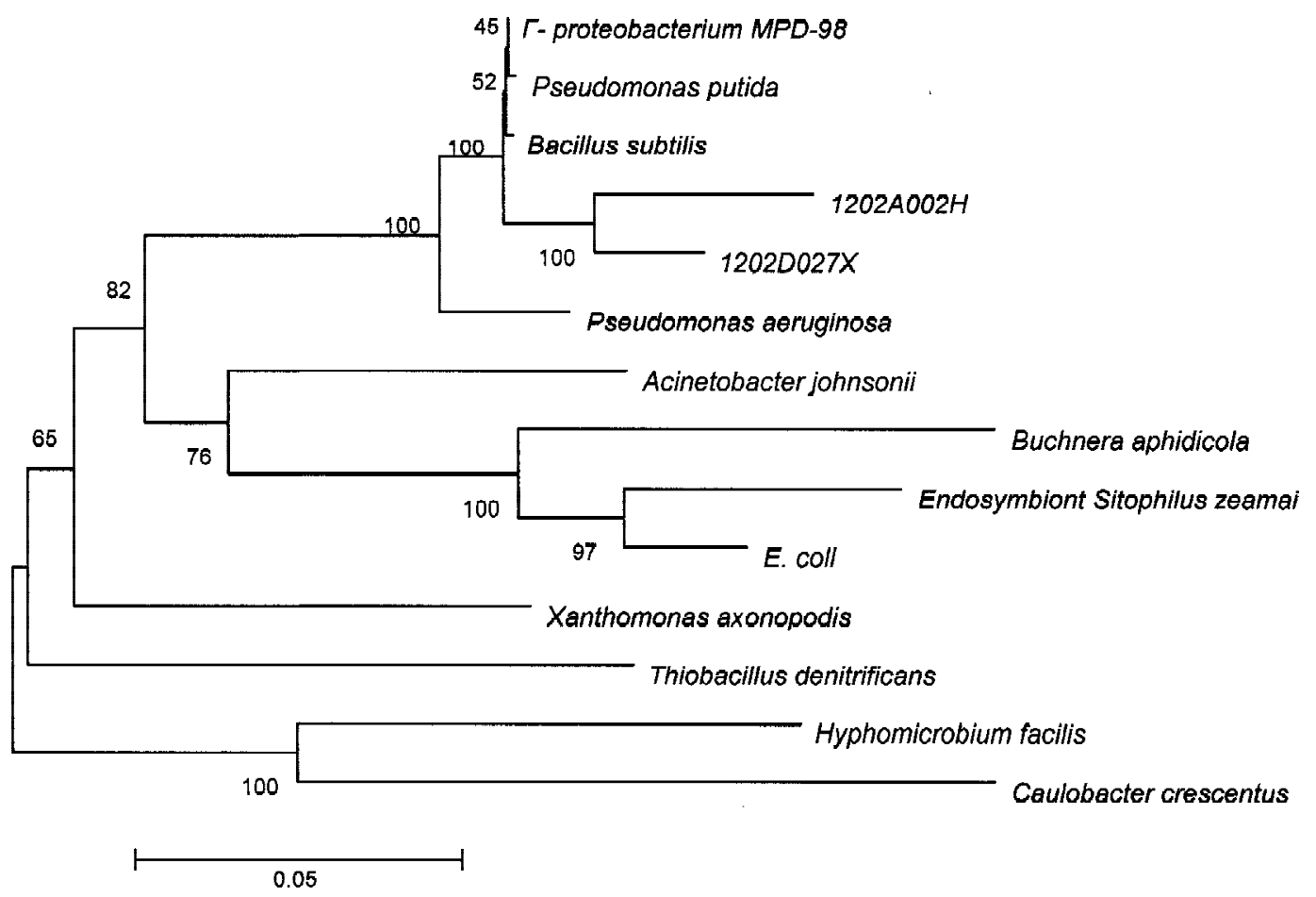

Fig. 2. Nighbor-joining (NJ) tree of the ribosomal ITS sequences of the bacteria obtained in this study and their allied sequences. GenBank accession numbers for the bacterial isolates for $1202 \mathrm{A002H}$ and $1202 \mathrm{D} 027 \mathrm{X}$ are AY563616 and AY563617, respectively. Scale bar 0.05 represents the genetically evolutionary distances for $16 \mathrm{~S}$ rRNAs.

Although the two isolates were morphologically identified as gram-positive rod-shaped bacteria for $1202 \mathrm{A002H}$ and gram-negative sphere-shaped bacteria for $1202 \mathrm{D} 027 \mathrm{X}$ using Gram stain technique, they were genetically identified as Bacillus subtilis and Pseudomonas putida or $\gamma$-proteobacterium MPD-98 strains. Except the genetically evolutional distances for $16 \mathrm{~S}$ rRNAs, the two isolates have very close $\mathrm{G}+\mathrm{C}$ contents to these bacteria, they are $50.34 \mathrm{~mol} \%$ for $1202 \mathrm{~A} 002 \mathrm{H}, 48.94 \mathrm{~mol} \%$ for $1202 \mathrm{~A} 027 \mathrm{X}, 50.53 \mathrm{~mol} \%$ for Pseudomonas putida, $51.43 \mathrm{~mol} \%$ for Pseudomonas aeruginosa, $50.99 \mathrm{~mol} \%$ for $\gamma$-proteobacterium MPD- 98, and $51.29 \mathrm{~mol} \%$ for Bacillus subtilis. Thus, the two isolates could be any two of Pseudomonas putida, $\gamma$-proteobacterium MPD- 98, Bacillus subtilis, and Pseudomonas aeruginosa. 
Our biochemical tests demonstrated that like Pseudomonas putida and Pseudomonas aeruginosa, the two isolates could utilize gelatin, D-glucose, L-arabinose, D-mannose, Dmannitol, N-acetyl-glucosamine, D-maltose, potassium gluconate, adipic acid, malic acid, trisodium citrate, and oxidase. However, the $1202 \mathrm{A002H}$ strain could utilize esculin ferric citrate, but not for capric acid and phenylacetic acid; in contrast, the $1202 \mathrm{D} 027 \mathrm{X}$ strain could not utilize esculin ferric citrate, but could be for capric acid and phenylacetic acid.

\subsection{Physiology of Bacterial Isolates}

\subsubsection{Temperature}

The experimental results of culturing sulfate-reducing bacteria show that the plateau phase occurs after $2-3$ days of culturing. The comparison among the five temperatures $\left(-10^{\circ} \mathrm{C}, 0^{\circ} \mathrm{C}\right.$, $30^{\circ} \mathrm{C}, 45^{\circ} \mathrm{C}$, and $60^{\circ} \mathrm{C}$ ) of bacterial culture in the sulfate-reducing media indicates that the bacteria grew at $0^{\circ} \mathrm{C}, 30^{\circ} \mathrm{C}$, and $45^{\circ} \mathrm{C}$ (Table 4). The bacteria grew fastest at $30^{\circ} \mathrm{C}(\sim 1-2$ days), followed by at $45^{\circ} \mathrm{C}(\sim 4-5$ days $)$ and at $0^{\circ} \mathrm{C}(1-2$ weeks $)$, but did not grow at $-10^{\circ} \mathrm{C}$ and $60^{\circ} \mathrm{C}$ for any sediment depths. Thus, the sulfate-reducing bacteria are most suitable for growing at $30^{\circ} \mathrm{C}$. A temperature range of $4.2-22.6^{\circ} \mathrm{C}$ is estimated for the sediments from the seafloor to a depth of $410 \mathrm{~m}$ on the basis of a temperature gradient of $0.045^{\circ} \mathrm{C} \mathrm{m}^{-1}$ estimated from the heat flow measurements of a nearby location $\left(24.76126^{\circ} \mathrm{N}, 122.50189^{\circ} \mathrm{E}\right)$ around the ODP drilling site KS-1 Site 26 (Shyu and Liu 2001). This range is consistent with the result of our culturing experiments of bacteria.

\subsubsection{Salinity}

Sulfate-reducing bacteria grew well (grown in two days) at 8.8 - 35\% salinity. These bacteria were halo-tolerant and could be salinity-resistant up to $60 \%$, but not $\geq 65 \%$ (Table 5). The results reveal that a brine incursion could stimulate bacterial activity and increase bacterial viability at the depth of $358.3 \mathrm{mbsf}$, a depth well beyond the previously reported depth of 80 mbsf in the Peru Margin by WDCMGG (2001).

The bacteria in the sediments collected from several depths $(10.1,119,186.5,241.2$, $250.8,270$, and $358.3 \mathrm{mbsf}$ ) could resist salinities up to $60-65 \%$ (data not shown) in our culturing experiments, but the growth rates of these halo-tolerant bacteria were low. The salinity of the sea surface water has been previously determined to be $33.6-34.8 \%$ (Hwang and Tang 1993). These values are similar to those reported for all of the down-core sediments used for this study (Huang et al. 2005). Although there are no salinity data available for the pore fluids at depths, it is expected to see higher pore-fluid salinity in the deeper sediments. For example, a high salinity of $106 \%$ of the pore fluid of the sediments at about $400 \mathrm{mbsf}$ in the south Australian margin of ODP Leg 182 was reported by Swart et al. (2000). However, the result in this study demonstrates the possibility for the existence of salinity-resistant bacteria in deep sediments that contain high-salinity brine, but high salinity does not appear to favor bacterial growth or their viability. 


\section{$3.3 .3 \mathrm{pH}$}

The optimal $\mathrm{pH}$ for the growth of the studied bacteria fell in the range of 7 - 8.3 (Table 6). A pH value of 7 was most favorable for the bacterial growth in the sediments of all depths. However, the bacteria that were extracted from the sediments of $10.1-29.1,119,186.5-270$, and 358.3 mbsf were alkaline-resistant at $\mathrm{pH}$ levels up to 10 at $30^{\circ} \mathrm{C}$ (Table 6). All the bacteria cultured from the sediments throughout the sequence could not grow at $\mathrm{pH} \leq 5$ or $\geq 11$.

Table 4. The bacterial growth conditions using sulfate-reducing medium at different temperatures from different depths of sediments.

\begin{tabular}{|c|c|c|c|c|c|c|}
\hline Sample no. & $\begin{array}{c}\text { Depth } \\
(\mathrm{mbsf})\end{array}$ & $-10^{\circ} \mathrm{C}$ & $0^{\circ} \mathrm{C}$ & $30^{\circ} \mathrm{C}$ & $45^{\circ} \mathrm{C}$ & $60^{\circ} \mathrm{C}$ \\
\hline $1202 \mathrm{~A} 001 \mathrm{H}$ & 3 & - & + & + & - & - \\
\hline $1202 \mathrm{~A} 002 \mathrm{H}$ & 10.1 & - & + & + & - & - \\
\hline $1202 \mathrm{~A} 004 \mathrm{H}$ & 29.1 & - & + & + & - & - \\
\hline $1202 \mathrm{~A} 006 \mathrm{H}$ & 49.6 & - & + & + & - & - \\
\hline $1202 \mathrm{~A} 009 \mathrm{H}$ & 78.1 & - & + & + & - & - \\
\hline $1202 \mathrm{~A} 012 \mathrm{H}$ & 106.6 & - & + & + & - & - \\
\hline $1202 \mathrm{D} 014 \mathrm{X}$ & 119 & - & + & + & - & - \\
\hline $1202 \mathrm{D} 020 \mathrm{X}$ & 176.8 & - & + & + & + & - \\
\hline $1202 \mathrm{D} 021 \mathrm{X}$ & 186.5 & - & + & + & - & - \\
\hline $1202 \mathrm{D} 027 \mathrm{X}$ & 241.2 & - & + & + & + & - \\
\hline $1202 \mathrm{D} 028 \mathrm{X}$ & 250.8 & - & + & + & + & - \\
\hline $1202 \mathrm{D} 030 \mathrm{X}$ & 270 & - & + & + & - & - \\
\hline $1202 \mathrm{D} 031 \mathrm{X}$ & 281.1 & - & + & + & + & - \\
\hline $1202 \mathrm{D} 032 \mathrm{X}$ & 290.8 & - & + & + & - & - \\
\hline $1201 \mathrm{D} 033 \mathrm{X}$ & 300.4 & - & + & + & - & - \\
\hline $1202 \mathrm{D} 035 \mathrm{X}$ & 319.6 & - & + & + & - & - \\
\hline $1202 \mathrm{D} 039 \mathrm{X}$ & 358.3 & - & + & + & - & - \\
\hline
\end{tabular}

+: with bacterial growth; -: without bacterial growth. 
Table 5. The bacterial growth conditions using sulfate-reducing medium at different salinity levels from different depths of sediments.

\begin{tabular}{|c|c|c|c|c|c|c|c|c|c|c|c|c|}
\hline Sample no. & $\begin{array}{c}\text { Depth } \\
\text { (mbsf) }\end{array}$ & $8.8 \% 0$ & $11 \% 0$ & $15 \% 0$ & $18 \%$ & $21 \% 0$ & $28 \% 0$ & $35 \%$ & $40 \% 0$ & $50 \% 0$ & $60 \% 0$ & $\geq 65 \% 0$ \\
\hline $1202 \mathrm{A001 \textrm {H }}$ & 3 & + & + & + & + & + & + & + & - & - & - & - \\
\hline $1202 \mathrm{~A} 002 \mathrm{H}$ & 10.1 & + & + & + & + & + & + & + & + & + & + & - \\
\hline $1202 \mathrm{~A} 004 \mathrm{H}$ & 29.1 & + & + & + & + & + & + & + & - & - & - & - \\
\hline $1202 \mathrm{~A} 006 \mathrm{H}$ & 49.6 & + & + & + & + & + & + & + & - & - & - & - \\
\hline $1202 \mathrm{~A} 009 \mathrm{H}$ & 78.1 & + & + & + & + & + & + & + & - & - & - & - \\
\hline $1202 \mathrm{~A} 012 \mathrm{H}$ & 106.6 & + & + & + & + & + & + & + & - & - & - & - \\
\hline $1202 \mathrm{D} 014 \mathrm{X}$ & 119 & + & + & + & + & + & + & + & + & + & + & - \\
\hline $1202 \mathrm{D} 020 \mathrm{X}$ & 176.8 & + & + & + & + & + & + & + & - & - & - & - \\
\hline $1202 \mathrm{D} 021 \mathrm{X}$ & 186.5 & + & + & + & + & + & + & + & + & + & + & - \\
\hline $1202 \mathrm{D} 027 \mathrm{X}$ & 241.2 & + & + & + & + & + & + & + & + & + & + & - \\
\hline $1202 \mathrm{D} 028 \mathrm{X}$ & 250.8 & + & + & + & + & + & + & + & + & + & + & - \\
\hline $1202 \mathrm{D} 030 \mathrm{X}$ & 270 & + & + & + & + & + & + & + & + & + & + & - \\
\hline $1202 \mathrm{D} 031 \mathrm{X}$ & 281.1 & + & + & + & + & + & + & + & - & - & - & - \\
\hline $1202 \mathrm{D} 033 \mathrm{X}$ & 300.4 & + & + & + & + & + & + & + & - & - & - & - \\
\hline $1202 \mathrm{D} 035 \mathrm{X}$ & 319.6 & + & + & + & + & + & + & + & - & - & - & - \\
\hline $1202 \mathrm{D} 039 \mathrm{X}$ & 358.3 & + & + & + & + & + & + & + & + & + & + & - \\
\hline
\end{tabular}

+ : with bacterial growth; -: without bacterial growth; salinity $=8.8 \%$, no extra $\mathrm{NaCls}$ were added; salinity $=11 \%, 0.125 \mathrm{~g} \mathrm{NaCls}$ were added; salinity $=15 \%$, $0.250 \mathrm{~g} \mathrm{NaCls}$ were added; salinity $=18 \%, 0.500 \mathrm{~g} \mathrm{NaCls}$ were added; salinity $=21 \% 0,0.750 \mathrm{~g} \mathrm{NaCls}$ were added; salinity $=28 \%, 1 \mathrm{~g} \mathrm{NaCls}$ were added; salinity $=35 \%, 1.3 \mathrm{~g} \mathrm{NaCls}$ were added; salinity $=40 \%, 1.5 \mathrm{~g} \mathrm{NaCls}$ were added; salinity $=50 \%, 2.0 \mathrm{~g} \mathrm{NaCls}$ were added; salinity $=60 \%, 2.5 \mathrm{~g} \mathrm{NaCls}$ were added; salinity $=65 \%, 2.8 \mathrm{~g} \mathrm{NaCls}$ were added. They were separately added to $50 \mathrm{ml}$ of sulfate-reducing medium. 
Table 6. The bacterial growth conditions using sulfate-reducing medium at different $\mathrm{pH}$ levels from different depths of sediments.

\begin{tabular}{|c|c|c|c|c|c|c|c|c|}
\hline Sample no. & Depth(mbsf) & $\mathrm{pH} 5$ & $\mathrm{pH} 6$ & $\mathrm{pH} 7$ & $\mathrm{pH} 8.3$ & $\mathrm{pH} 9.5$ & $\mathrm{pH} 10$ & $\mathrm{pH} 11$ \\
\hline $1202 \mathrm{A001 \textrm {H }}$ & 3 & - & + & + & + & + & - & - \\
\hline $1202 \mathrm{~A} 002 \mathrm{H}$ & 10.1 & - & + & + & + & + & + & - \\
\hline $1202 \mathrm{~A} 004 \mathrm{H}$ & 29.1 & - & + & + & + & + & + & - \\
\hline $1202 \mathrm{~A} 006 \mathrm{H}$ & 49.6 & - & + & + & + & - & - & - \\
\hline $1202 \mathrm{~A} 009 \mathrm{H}$ & 78.1 & - & - & + & + & + & - & - \\
\hline $1202 \mathrm{~A} 012 \mathrm{H}$ & 106.6 & - & + & + & - & - & - & - \\
\hline $1202 \mathrm{D} 014 \mathrm{X}$ & 119 & - & + & + & + & + & + & - \\
\hline $1202 \mathrm{D} 020 \mathrm{X}$ & 176.8 & - & - & + & + & - & - & - \\
\hline $1202 \mathrm{D} 021 \mathrm{X}$ & 186.5 & - & + & + & + & + & + & - \\
\hline $1202 \mathrm{D} 027 \mathrm{X}$ & 241.2 & - & + & + & + & + & + & - \\
\hline $1202 \mathrm{D} 028 \mathrm{X}$ & 250.8 & - & + & + & + & + & + & - \\
\hline $1202 \mathrm{D} 030 \mathrm{X}$ & 270 & - & + & + & + & + & + & - \\
\hline $1202 \mathrm{D} 031 \mathrm{X}$ & 281.1 & - & + & + & + & - & - & - \\
\hline $1202 \mathrm{D} 033 \mathrm{X}$ & 300.4 & - & + & + & + & + & - & - \\
\hline $1202 \mathrm{D} 035 \mathrm{X}$ & 319.6 & - & - & + & + & - & - & - \\
\hline $1202 \mathrm{D} 039 \mathrm{X}$ & 358.3 & - & - & + & + & + & + & - \\
\hline
\end{tabular}

+: with bacterial growth; -: without bacterial growth.

\subsection{Bacterial Activity}

\subsubsection{Bacterial Population and Motility}

Bacteria could be isolated from the seafloor surface down to $358.3 \mathrm{mbsf}$ (1202D039X) using the fermentative and sulfate-reducing media (Table 3). The bacteria in the deep sediments (300.4 mbsf) were adapted to aerobic conditions (G- spheres). Except for the rod-shaped bacteria found at depths of $3-29.1,250.8$, and $281.1 \mathrm{mbsf}$, the bacteria identified from the sediments at all other depths were sphere-shaped bacteria. The indigenous bacteria harbored in the sediments from the seafloor surface down to $358.3 \mathrm{mbsf}$ cover a range of bacterial population from $53 \times 10^{7}-217 \times 10^{7}$ cells per gram sediment (Table 3 ). The bacterial populations did not decrease with depth. This is because extreme bioturbation disturbance and dis- 
ruption by gas voids could allow bacteria to migrate through a different depth of sediments. These indigenous bacteria in the sediments (1.62 to $64.73 \mathrm{ka}$ in age of sediment) could be either motile or non-motile (Table 3). Bacterial growth conditions at different temperature, salinity, and $\mathrm{pH}$ levels from different depths of sediments do not appear to relate to the motility distribution.

\subsubsection{Changes in Cations and Anions after Culturing}

After the bacteria were cultured in sulfate-reducing media, the changes in the concentrations of cations $\left(\mathrm{Na}^{+}, \mathrm{NH}_{4}{ }^{+}, \mathrm{K}^{+}, \mathrm{Mg}^{2+}, \mathrm{Ca}^{2+}, \mathrm{Cu}^{2+}\right.$, and $\left.\mathrm{Fe}\right)$ and anions $\left(\mathrm{F}^{-}, \mathrm{Br}^{-}, \mathrm{SO}_{4}{ }^{2-}\right)$ were measured using ion chromatography techniques. The ionic concentrations show significant variations as compared to the control (i.e., before culturing) (Tables 7, 8, and Figs. 3, 4). Although the bacteria were cultured in sulfate-reducing media, the bacteria from samples of all depths did not utilize but released $\mathrm{NH}_{4}{ }^{+}, \mathrm{Br}^{-}$, and $\mathrm{SO}_{4}{ }^{2-}$ into the media as their concentrations increased after culturing. Instead, $\mathrm{Fe}$ was depleted by the bacteria at different depths. $\mathrm{Na}^{+}, \mathrm{K}^{+}, \mathrm{Mg}^{2+}$, and $\mathrm{Ca}^{2+}$ were consumed, while $\mathrm{Cu}^{2+}$ and $\mathrm{F}^{-}$were either consumed or non-consumed but released from bacteria. These analyzed elements were included in the media (Table 2). In addition, concentrations of Mn, Co, Zn, and Se were measured by an ICP-MS. The concentrations of $\mathrm{Mn}, \mathrm{Co}, \mathrm{Zn}$, and Se were not depleted by bacterial activities (data not shown). These observations suggest that the identified bacteria may consume some of the analyzed elements to some extent for reproduction and growth in the sediments of all depths ( 3 - $358.3 \mathrm{mbsf}$ ) and that the indigenous bacteria from the sediments of different depths have different physiological and biochemical characteristics.

It should be noticed that microorganism enriched from sulfate-reducing medium may not be sulfate-reducing bacteria. The two isolates $(1202 \mathrm{A002H}$ and $1202 \mathrm{D} 027 \mathrm{X})$ were cultured in sulfate-reducing medium and identified as Bacillus subtilis and Pseudomonas putida or $\gamma$-proteobacterium MPD-98 strains, which are not sulfate-reducing bacteria. Instead, the strains are sulfur-oxidizing bacteria. Because both of sulfate-reducing and sulfur-oxidizing media contain sulfur, the cultured bacteria could grow on reduced sulfur compounds (e.g., sulfide, sulfur, and organic sulfides) and then oxidize them in anaerobic conditions to sulfate, which was then released to the media. Our experimental results show that sulfate concentrations at all depths of sediments increased (Table 8 and Fig. 4) after enrichment from sulfate-reducing medium, but sulfide $\left(\mathrm{S}^{2-}\right)$ concentrations decreased by $7.1-66.7 \%$ (data not shown) relative to the concentrations, including those eluting from sediments and culture medium without bacteria.

\subsection{Mineralogical Analysis}

X-ray diffraction and SEM analyses suggest that detrital chlorite, illite, and quartz are the main mineral constituents of the sediments at all depths (Fig. 5). No positive identification of biogenic minerals such as iron sulfides or carbonates could be made in this study. The chemical changes generated or induced by the microbes were probably not significant enough to produce biogenic minerals. 
Table 7. The changes in cation concentrations for the products of sulfate-reducing media after bacterial metabolism relative to the control.

\begin{tabular}{|c|c|c|c|c|c|}
\hline \multirow[b]{2}{*}{ Sample no. } & \multirow[b]{2}{*}{ Depth (mbsf) } & \multicolumn{2}{|r|}{$\mathrm{Cu}^{2+}\left(\mu \mathrm{gl}^{-1}\right)$} & \multicolumn{2}{|c|}{$\mathrm{Fe}\left(\mu \mathrm{gl}^{-1}\right)$} \\
\hline & & Control & $\begin{array}{l}\text { After } \\
\text { biodegradation }\end{array}$ & Control & $\begin{array}{l}\text { After } \\
\text { biodegradation }\end{array}$ \\
\hline $1202 \mathrm{~A} 001 \mathrm{H}$ & 3 & 700.8 & $545.6(-22.1 \%)$ & 2250.4 & $89.9(-96.0 \%)$ \\
\hline $1202 \mathrm{~A} 002 \mathrm{H}$ & 10.1 & 653.8 & $607.2(-7.1 \%)$ & 1087.6 & $97.9(-91.0 \%)$ \\
\hline $1202 \mathrm{~A} 004 \mathrm{H}$ & 29.1 & 623.0 & $632.7(+1.6 \%)$ & 2319.1 & $175.5(-92.4 \%)$ \\
\hline $1202 \mathrm{~A} 006 \mathrm{H}$ & 49.6 & 605.3 & $641.0(+5.9 \%)$ & 2446.6 & $162.0(-93.4 \%)$ \\
\hline $1202 \mathrm{~A} 009 \mathrm{H}$ & 78.1 & 598.2 & $624.2(+4.3 \%)$ & 1911.1 & $88.6(-95.8 \%)$ \\
\hline $1202 \mathrm{~A} 012 \mathrm{H}$ & 106.6 & 617.8 & $644.4(+4.3 \%)$ & 2973.1 & $52.3(-98.2 \%)$ \\
\hline $1202 \mathrm{D} 014 \mathrm{X}$ & 119 & 589.5 & $561.4(-4.8 \%)$ & 2459.2 & $111.0(-95.5 \%)$ \\
\hline $1202 \mathrm{D} 020 \mathrm{X}$ & 176.8 & 586.1 & $596.8(+1.8 \%)$ & 3144.7 & $61.5(-98.0 \%)$ \\
\hline $1202 \mathrm{D} 021 \mathrm{X}$ & 186.5 & 587.4 & $682.4(+16.2 \%)$ & 4401.7 & $60.6(-98.6 \%)$ \\
\hline $1202 \mathrm{D} 027 \mathrm{X}$ & 241.2 & 589.3 & $611.6(+3.8 \%)$ & 6156.7 & $62.7(-99.0 \%)$ \\
\hline $1202 \mathrm{D} 028 \mathrm{X}$ & 250.8 & 571.1 & $545.7(-4.4 \%)$ & 1841.8 & $0(-100 \%)$ \\
\hline $1202 \mathrm{D} 030 \mathrm{X}$ & 270 & 572.1 & $575.7(+0.6 \%)$ & 1994.5 & $28.6(-98.6 \%)$ \\
\hline $1202 \mathrm{D} 031 \mathrm{X}$ & 281.1 & 570.0 & $496.9(-12.8 \%)$ & 3558.7 & $20.7(-99.4 \%)$ \\
\hline $1202 \mathrm{D} 033 \mathrm{X}$ & 300.4 & 572.3 & $500.0(-12.6 \%)$ & 3591.7 & $75.9(-97.9 \%)$ \\
\hline $1202 \mathrm{D} 035 \mathrm{X}$ & 319.6 & 566.9 & $518.0(-8.6 \%)$ & 2340.7 & $5.0(-99.8 \%)$ \\
\hline $1202 \mathrm{D} 039 \mathrm{X}$ & 358.3 & 571.5 & $548.9(-3.9 \%)$ & 4047.7 & $18.6(-99.5 \%)$ \\
\hline
\end{tabular}

Control: The concentrations included those eluting from sediments and culture medium without bacteria.

( ) represents the percentage for the change in concentration, + for increase and - for decrease. 
Table 7. Contuined.

\begin{tabular}{|c|c|c|c|c|c|c|c|}
\hline & $\mathrm{Na}^{+}\left(\mathrm{mg} \mathrm{l}^{-1}\right)$ & & $\mathrm{Ca}^{2+}\left(\mathrm{mg} \mathrm{l}^{-1}\right)$ & & $\mathrm{K}^{+}\left(\mathrm{mg} \mathrm{l}^{-1}\right)$ & & $\mathrm{Mg}^{2+}\left(m g l^{-1}\right)$ \\
\hline & After & & After & & After & & After \\
\hline Control & biodegradation & Control & biodegradation & Control & biodegradation & Control & biodegradation \\
\hline 5529.3 & $4593.7(-16.9 \%)$ & 25.4 & $9.9(-60.9 \%)$ & 469.3 & $408.7(-12.9 \%)$ & 55.9 & $36.7(-34.3 \%)$ \\
\hline 5598.1 & $4530.9(-19.1 \%)$ & 27.3 & $18.1(-33.6 \%)$ & 468.7 & $407.9(-13.0 \%)$ & 56.3 & $42.5(-24.59$ \\
\hline 5606.8 & $4480.3(-20.1 \%)$ & 27.1 & $6(-68.4 \%)$ & 468.8 & $401.4(-14.4 \%)$ & 56.3 & $3 \mid 42.3(-25.0 \%)$ \\
\hline 5601.4 & $4275.5(-23.7 \%)$ & 25.5 & $6.8(-73.2 \%)$ & 468.7 & $379.3(-19.1 \%)$ & 56.0 & $38.6(-31.1 \%$ \\
\hline 5605.3 & 4228. & 28.3 & $8 \%)$ & 469.6 & $378.4(-19.4 \%)$ & 57.0 & $.8 \%$ \\
\hline 5596.7 & $4395.6(-21.5 \%)$ & 29.4 & $8.7(-70.4 \%)$ & 469.1 & $390.4(-16.8 \%)$ & 56.6 & $42.7(-24.7 \%)$ \\
\hline 5603.6 & $4313.4(-23.0 \%)$ & 28.5 & $3.9(-86$ & 469.7 & 378.5 & 57.2 & 37.7 \\
\hline 5617.7 & $4448.5(-20.8 \%)$ & 29.7 & $7.0(-76.4 \%)$ & 468.7 & $392.1(-16.3 \%)$ & 56.4 & $43.1(-23.7 \%)$ \\
\hline 5625.2 & $4188.5(-25.5 \%)$ & 27.4 & $17.1(-37.6 \%)$ & 470.8 & $372.2(-20.9 \%)$ & 58.1 & $40.9(-29.6 \%)$ \\
\hline 5598.9 & $4152.0(-25.8 \%)$ & 28.5 & $10.4(-63.5 \%)$ & 470.1 & $372.0(-20.9 \%)$ & 56.8 & $42.9(-24.4 \%)$ \\
\hline 5607.8 & $4592.1(-18.1 \%)$ & 29.6 & $14.2(-52.0 \%)$ & 469.6 & $409.3(-12.8 \%)$ & 56.4 & $49.4(-12.4 \%)$ \\
\hline 5613.5 & $3670.2(-34.6 \%)$ & 30.1 & $7.4(-75.3 \%)$ & 469.3 & $286.9(-38.9 \%)$ & 56.8 & $29.3(-48.4 \%)$ \\
\hline 5600.0 & $4487.6(-19.9 \%)$ & 28.8 & $5.8(-79.8 \%)$ & 471.1 & $393.6(-16.4 \%)$ & 57.6 & $5 \quad 37.8(-34.4 \%)$ \\
\hline 5612.9 & $4400.7(-21.6 \%)$ & 30.5 & $8.3(-72.8 \%)$ & 470.3 & $388.8(-17.3 \%)$ & 56.9 & $41.4(-27.4 \%)$ \\
\hline 5605.4 & $4375.4(-21.9 \%)$ & 30.2 & $6.9(-77.1 \%)$ & 470.3 & $375.3(-20.2 \%)$ & 56.9 & $35.7(-37.2 \%)$ \\
\hline 5613.5 & $4571.0(-18.6 \%)$ & 30.6 & $7.5(-75.6 \%)$ & 468.8 & $403.0(-14.0 \%)$ & 55.4 & $42.8(-22.8 \%)$ \\
\hline
\end{tabular}

\section{CONCLUSIONS}

The sulfate-reducing bacteria extracted and cultured from the Okinawa Trough sediments grew best at temperature $=30^{\circ} \mathrm{C}$, salinity $=8.8-35 \%$, and $\mathrm{pH}=7-8.3$ in the experiments carried out in this study. However, the bacteria could survive at temperatures up to $45^{\circ} \mathrm{C}$, salinity up to $60-65 \%$, and $\mathrm{pH}$ up to 10 . The sequence identity comparison across bacterial strains showed that the bacteria extracted from the sediments at all depths were sphere-shaped bacteria with the exception of rod-shaped bacteria being also found at depths of $3-29.1,250.8$, and 281.1 mbsf. The relatively low reproduction rates of bacteria isolated from the sediments at depths up to $358.3 \mathrm{mbsf}$ in rather high salinity conditions demonstrate the existence of salinity-resistant and halo-tolerant bacteria in deep sediments and suggest that bacterial growth 
or viability does not appear to be always favored by high salinity conditions. The indigenous bacteria have the capability of consuming $\mathrm{Fe}, \mathrm{Cu}^{2+}, \mathrm{K}^{+}, \mathrm{Na}^{+}, \mathrm{Mg}^{2+}, \mathrm{Ca}^{2+}$, and $\mathrm{F}^{-}$during culturing, but no biogenic minerals were found. This study identifies the bacterial activity that extends from the seafloor surface down to $358.3 \mathrm{mbsf}$, being adapted to either aerobic or facultatively anaerobic conditions.

Table 8. The changes in anion concentrations for the products of sulfate-reducing media after bacterial metabolism relative to the control.

\begin{tabular}{|c|c|c|c|c|c|c|c|}
\hline \multirow[b]{2}{*}{ Sample no. } & \multirow[b]{2}{*}{$\begin{array}{c}\text { Depth } \\
\text { (mbsf) }\end{array}$} & \multicolumn{2}{|r|}{$F^{-}\left(m g l^{-1}\right)$} & \multicolumn{2}{|r|}{$\mathrm{Br}^{-}\left(\mathrm{mgl}^{-1}\right)$} & \multicolumn{2}{|r|}{$\mathrm{SO}_{4}{ }^{2-}\left(\mathrm{mg} \mathrm{l}^{-1}\right)$} \\
\hline & & & $\begin{array}{l}\text { After } \\
\text { biodegradati }\end{array}$ & or & $\begin{array}{l}\text { After } \\
\text { biodegradati }\end{array}$ & introl & $\begin{array}{l}\text { After } \\
\text { biodegradatic }\end{array}$ \\
\hline 12 & 3 & 254.0 & b) & 1018.5 & 2096 & | 1710.00 & 200 \\
\hline 120 & 10.1 & 254.0 & $\%$ & 1012.7 & 2067 & 1714.08 & 2629. \\
\hline 1202 & 29.1 & 254.0 & b) & 1015.1 & & 1720.36 & $2584.4(+50.2 \%$ \\
\hline 120 & 49.6 & 2 & 40036 & 6 & 1900 & 60 & 2420 \\
\hline 12 & .1 & 2 & o) & 17.2 & 20 & 720.27 & 2007.2 \\
\hline 1202 & 6.6 & 254 & $413.4(+62.7 \%)$ & 1012.6 & 2000. & 1715.19 & $2540.9(+48.1 \%)$ \\
\hline 1202 & 119 & 254.0 & $403.7(+58.9 \%)$ & 1020.7 & $2049.7(+100.8 \%)$ & 1704.01 & $2610.4(+53.2 \%)$ \\
\hline 12 & 6.8 & 2 & 6) & 1014.2 & 20 & 1705.45 & $+51.5 \%$ \\
\hline 1202 & 186.5 & 254.0 & $53.6 \%)$ & 1034.6 & 2046 & 1699.18 & (F. \\
\hline 12 & 2 & 2 & $47.3 \%)$ & 1022.2 & $6.96 \%)$ & 1708.21 & $2427.9(+42.1 \%)$ \\
\hline 1202 & 250.8 & 254 & 6) & 1022.1 & 19 & 1150.11 & $2514.4(+44.9$ \\
\hline 12 & 0 & 25 & $19.9(-92.2 \%)$ & 1017.1 & 21 & 1734.72 & 26 \\
\hline 1202D031X & 281.1 & 254.0 & 390. & 1028.7 & 20 & 1726.98 & \begin{tabular}{|l|l}
3 & 259
\end{tabular} \\
\hline 12 & 4 & 2 & )) & 1009.3 & 2015 & 1735 & $2570.9(+48.1$ \\
\hline 1202 & 319.6 & 254.0 & $4 \%)$ & 1021.1 & $1910.04+$ & 1720.59 & $2423.3(+40.8 \%)$ \\
\hline 20-2 & 58.3 & 254.0 & $430.4(+69.4 \%)$ & 1010.7 & $2118.1(+109.6 \%)$ & 175 & $2696.2\left(+53.8^{\circ}\right.$ \\
\hline
\end{tabular}

Control: The concentrations included those eluting from sediments and culture medium without bacteria.

( ) represents the percentage for the change in concentration, + for increase and - for decrease. 


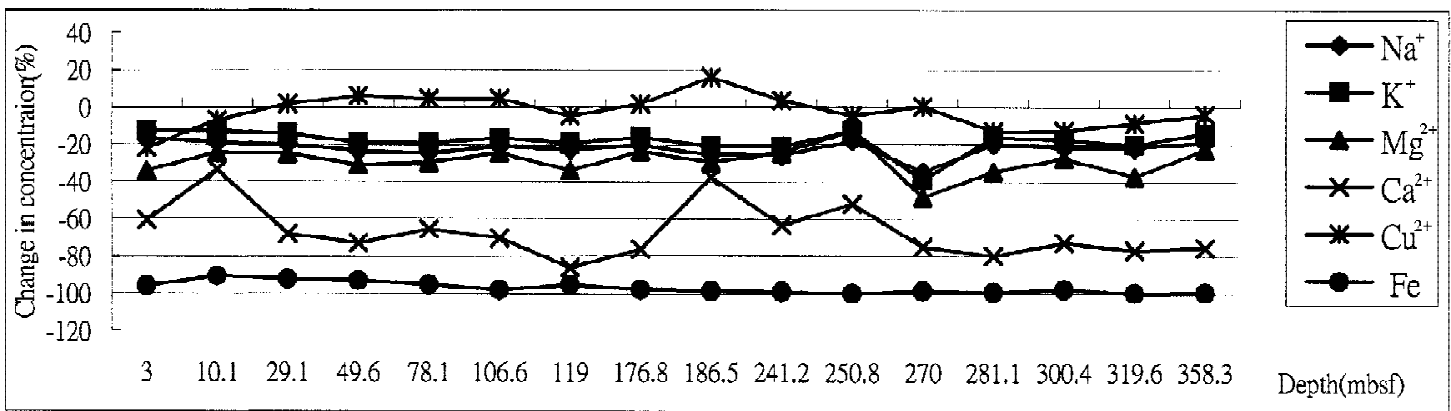

Fig. 3. Changes of cationic concentrations relative to the control after bacterial culturing from the studied sediments of various depths in the sulfatereducing media.

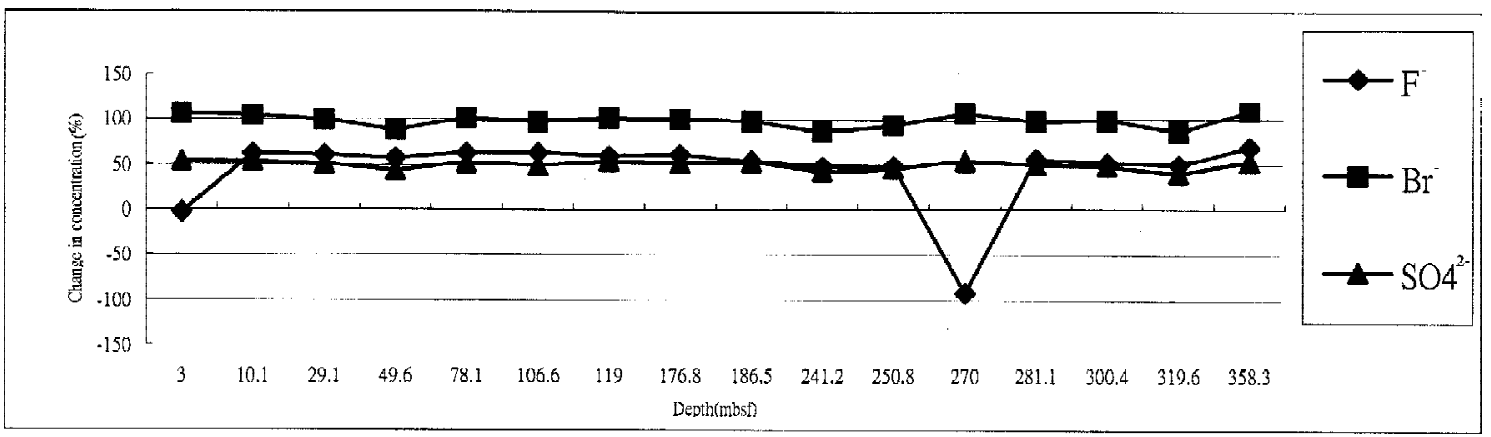

Fig. 4. Variations of anionic concentrations relative to the control after bacterial culturing from the studied sediments of various depths in the sulfatereducing media.

Acknowledgements The authors thank the Ocean Drilling Program at Texas A\&M University and the Leg 195 Shipboard Scientific Party for kindly providing us with sediment samples from the Holes A and D of Site 1202, ODP Leg 195. This work was supported by the National Science Council (Grant NSC91-2116-M-006-006). The authors are grateful to Mr. ChingMing Wu (Department of Cell Biology and Anatomy of National Cheng Kung University Medical College) for helping the observations of bacterial morphology using transmission electron and phase-contrast microscopies, and to Mr. Teng-Fan Lai, Ms. I-Ting Chen, and Mr. Yih-Fenn Cheng for bacterial culturing of this study. 

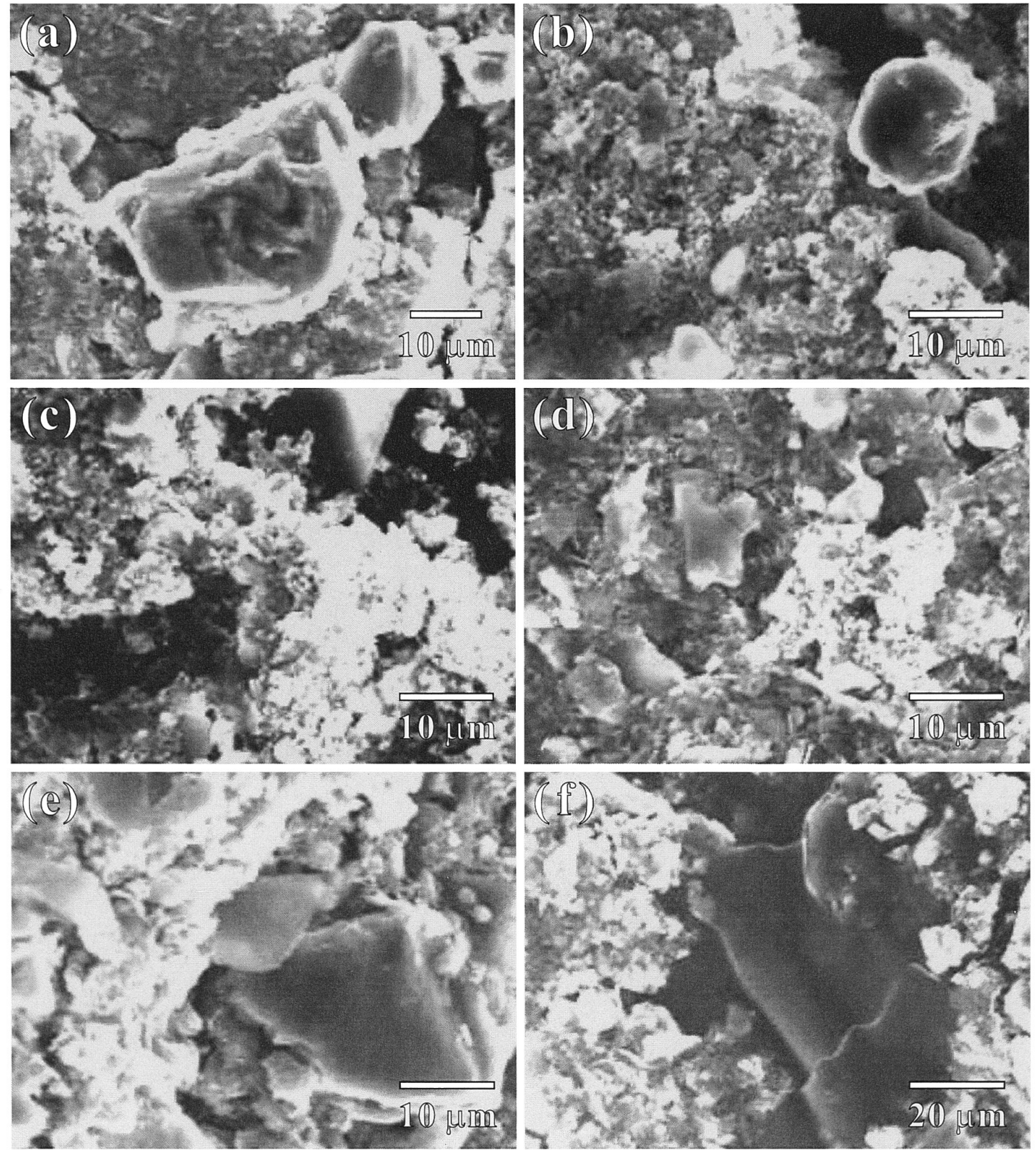

Fig. 5. Scanning electron micrographs of the products of bacterial metabolism from the sediments collected from $176.8 \mathrm{mbsf}$ (a), $281.1 \mathrm{mbsf}$ (b and c), $300.4 \mathrm{mbsf}$ (d and e), and $319.6 \mathrm{mbsf}$ (f). 


\section{REFERENCES}

Bennasar, A., C. Guasp, and J. Lalucat, 1998: Molecular methods for the detection and identification of Pseudomonas stutzeri in pure culture and environmental samples. Microbial Ecol., 35, 22-33.

Bidle, K. A., M. Kastner, a=nd D. H. Bartlett, 1999: A phylogenetic analysis of microbial communities associated with methane hydrates containing marine fluids and sediments in the Cascadia margin (ODP Site 829B). FEMS Microbiol. Lett., 177, 101-108.

Bird, D. F., S. K. Juniper, M. Ricciard-Rigault, P. Martineu, Y. T. Prairie, and S. E. Calvert, 2001: Subsurface viruses and bacteria in Holocene/Late Pleistocene sediments of Saanich Inlet, BC: ODP Holes 1033B and 1034B, Leg 169S. Marine Geol., 174, 227-239.

Blakemore, R. P., D. Maratea, and R. S. Wolfe, 1979: Isolation and pure culture of a freshwater magnetic spirillum in chemically defined medium. J. Bacteriol., 140, 702-709.

Boggs, S., Jr., W. C. Wang, F. S. Lewis, and J. C. Chen, 1979: Sediment properties and water characteristics of the Taiwan shelf and slope. Acta Oceanogr. Taiwanica, 10, 10-49.

Chen, M. P., S. C. Lo, and K. L. Lin, 1992: Composition and texture of surface sediment indicating the depositional environments off northeast Taiwan. Terr. Atmos. Ocean. Sci., 3, 395-418.

Cragg, B. A., R. J. Parks, J. C. Fry, A. J. Weightman, P. A. Rochelle, and J. R. Maxwell, 1994: Bacterial populations and processes in sediments containing gas hydrates (ODP Leg 146: Cascadia Margin). Global Biogeochem. Cycles, 8, 451-463.

Cragg, B. A., K. M. Law, G. M. O’Sullivan, and R. J. Parkes, 1999: Bacterial profiles in deep sediments of the Alboran Sea, Western Mediterranean, Sites 976-978. Proc. Ocean Drilling Prog., Scientific Results, 161, 433-438.

Felsenstein, J., 1985: Confidence limits on phylogenies: an approach using the bootstrap. Evolution, 39, 783-791.

Frankel, R. B., R. P. Blakemore, and R. S. Wolfe, 1979: Magnetite in freshwater magnetotactic bacteria. Science, 203, 1355-1356.

Huang, K. F., C. F. You, M. L. Shen, and H. L. Lin, 2005: Geochemistry of major constituents, boron and boron isotopes in pore waters from ODP Site 1202, Okinawa Trough.Terr. Atmos. Ocean. Sci., 16, 75-93.

Hwang, S. J., and T. Y. Tang, 1993: CTD data bank data report. Regional Instrument Center R/V Ocean Researcher I. Nat. Scie. Coun., Taipei, Taiwan, ROC.

Jensen, E. C., H. S. Schrader, B. Rieland, T. L. Thompson, K. W. Lee, K. W. Nickerson, and T. A. Kokjohn, 1998. Prevalence of broad-host-range lytic bacteriophages of sphaerotilus natans, Escherichia coli, and Pseudomonas aeruginosa. Applied Environ. Microbiol., 64, 575-580.

Kimura, M., 1980: A simple method for estimating evolutionary rates of base substitutions through comparative studies of nucleotide sequences. J. Molecular Evolution, 16, 111120.

Kormas, K. A., D. C. Smith, V. Edgcomb, and A. Teske, 2003: Molecular analysis of deep subsurface microbial communities in Nankai Trough sediments (ODP Leg 190, Site 1176). FEMS Microbiol. Ecol., 45, 115-125. 
Kumar, S., K. Tamura, I. B. Jakobsen, and M. Nei, 2001: MEGA2: molecular evolutionary genetics analysis software. Bioinformatics, 17, 1244-1245.

Lehman, R. M., F. S. Colwell, D. B. Ringelberg, and D. C. White, 1995: Combined microbial community-level analyses for quality assurance of terrestrial subsurface cores. $J$. Microbiolog. Methods, 22, 262-281.

Leu, J. Y., C. P. McGovern-Traa, A. J. R. Porter, and W. A. Hamilton, 1999: The same species of sulfate-reducing Desulfomicrobium occur in different oil field environment in the North Sea. Lett. Appl. Microbiol., 29, 246-252.

Lin, F. T., and J. C. Chen, 1983: Textural and mineralogical studies of sediments from the southern Okinawa Trough. Acta Oceanogr. Taiwanica, 14, 26-41.

Liu, S. V., J. Zhou, C. Zhang, D. R. Cole, M. Gajdarziska-Josifovska, and T. J. Phelps, 1997: Thermophyllic Fe(III)-reducing bacteria from the deep subsurface: The evolutionary implications. Science, 277, 1107-1109.

Mann, S., N. H. C. Sparks, R. B. Frankel, D. A. Bazylinski, and H. W. Jannasch, 1990: Biomineralization of ferrimagnetic gregite $\left(\mathrm{Fe}_{3} \mathrm{~S}_{4}\right)$ and iron pyrite $\left(\mathrm{FeS}_{2}\right)$ in a megnetotactic bacterium. Nature, 343, 259-261.

Rochelle, P. A., B. A. Cragg, J. C. Fry, R. J. Parkes, and A. J. Weightman, 1994: Effect of sample handling on estimation of bacterial diversity in marine sediments by $16 \mathrm{~S}$ rRNA gene sequence analysis. FEMS Microbiol. Ecol., 15, 215-226.

Shipboard Scientific Party, 2002: Site 1202. In Salisbury, M. H., Shinohara, M., Richter, C., et al., Proc. Init. Repts., 195, 1-46 [CD-ROM], Available from: Ocean Drilling Prog., Texas A\&M University, College Station, TX 77845-9547, USA.

Shyu, C. T. and C. S. Liu, 2001: Heat flow of the southwestern end of the Okinawa Trough. Terr. Atmos. Ocean. Sci., 12, 305-317.

Somerville, C. C., I. T. Knight, W. L. Straube, and R. R. Colwell, 1992: Simple, rapid method for direct isolation of nucleic acids from aquatic environments. Proc. Nat. Academy Scie. United States Am., 89, 5685-5689.

Swart, P. K., U. G. Wortmann, R. M. Mitterer, M. J. Malone, R. L. Smart, D. A. Feary, and A. C. Hine, 2000: Hydrogen sulfide-rich hydrates and saline fluids in the continental margin of south Australia. Geology, 28, 1039-1042.

Thompson, J. D., T. J. Gibson, F. Plewniak, F. Jeanmougin, and D. G. Higgins, 1997: The Clustal $\mathrm{X}$ windows interface: flexible strategies for multiple sequence alignment aided by quality analysis tools. Nucleic Acid Res., 24, 4876-4882.

WDCMGG (World Data Center for Marine Geology \& Geophysics), 2001: Core data from the Ocean Drilling Program Legs 101-129, Leg 112, Peru Continental Margin. World Data Center for Marine Geology \& Geophysics for MGG Seafloor Series, Vol. 2.

Webster, G., C. J. Newberry, J. C. Fry, and A. J. Weightman, 2003: Assessment of bacterial community structure in the deep sub-seafloor biosphere by $16 \mathrm{~S}$ rDNA-based techniques: a cautionary tale. J. Microbiolog. Methods, 55, 155-164.

Wei, K. Y., H. S. Mii, and C. Y. Huang, 2005: Age model and oxygen isotope stratigraphy of ODP Site 1202 in southern Okinawa Trough, northwestern Pacific.Terr. Atmos. Ocean. Sci., 16, 1-17. 
Weinbauer, M. G., C. Beckmann, and M. G. Hofle, 1998. Utility of green fluorescent nucleic acid dyes and aluminum oxide membrane filters for rapid epifluorescence enumeration of soil and sediment bacteria. Appl. Environ. Microbiol., 64, 5000-5003.

Whiticar, M. J., J. C. Sample, and R. Stein, 1995: Bacterial profiles in deep sediments of the Santa Barbara Basin, Site 893. In: Kennett, J. P. et al. (Eds.), Proc. Ocean Drilling Prog., Scientific Results, 146, 139-144. 